\title{
MODEL OF AN OPTIMAL PUBLIC-PRIVATE PARTNERSHIP PROJECT IN THE TELECOMMUNICATIONS SECTOR
}

\author{
Svetlana V. MALTSEVA \\ Professor, Department of Innovation and Business in Information Technologies, \\ National Research University Higher School of Economics \\ Address: 20, Myasnitskaya Street, Moscow, 101000, Russian Federation \\ E-mail: smaltseva@hse.ru
}

\section{Polina V. KOTELNIKOVA}

Post-graduate Student, Department of Innovation and Business in Information Technologies, National Research University Higher School of Economics;

Chief Inspector, Russian Accounts Chamber

Address: 20, Myasnitskaya Street, Moscow, 101000, Russian Federation

E-mail: kotelnikovapolina@gmail.com

This article presents an investment project model in the telecommunications sector using public-private partnership $(P P P)$, making it possible to link the main project parameters (duration, volume of investments, fare, request) with the expected indexes of effectiveness. When considering the project parameters and indexes of effectiveness, interests of both the state and private company are taken into account.

The modeling algorithm and criteria of performance evaluation are developed based on the standards approved for evaluation of investment projects with state participation, namely the Guidelines on performance evaluation of the investment projects approved by the Ministry of Economy, Ministry of Finance, State Construction Committee of the Russian Federation on June 21, 1999, No. VK 477.

This paper assumes that the most important criterion for evaluation of project effectiveness of a private company is the maximum of the net present value of the project, meaning the excess of the total cash receipts over the total cost for the project with regard to disparity of the effects (costs and benefits) related to different moments in time. Therefore, the higher this index, the greater is the interest of a private company to participate in the project.

It seems that from the standpoint of the state two factors are most important: the social significance of the project and minimum expenses of the state for implementation of the investment project under conditions of a limited capacity of spending budget funds. The social significance of the project is defined by expert study as the impact of the operational results on at least one of the domestic or foreign markets: financial markets, product and service markets, labor market, etc., as well as the ecological and social environment.

The model makes it possible to calculate various scenarios to determine optimal project parameters ensuring maximum efficiency for a given limit on the amount of budget investments.

The calculation results for the proposed model can be used to make decisions to participate in the project by the authorities or public development finance institutions. It is proposed to document the model used and its evaluation criteria in the rules of granting subsidies for such projects.

Key words: public-private partnership, investment project, project effectiveness, simulation, telecommunications.

Citation: Maltseva S.V., Kotelnikova P.V. (2015) Model of an optimal public-private partnership project

in the telecommunications sector. Business Informatics, no. 4 (34), pp. 24-31. DOI: 10.17323/1998-0663.2015.4.24.31. 


\section{Introduction}

$\mathrm{T}$ The telecommunications sector is a high-tech industry and plays an important role in the development of the national economy and its competitiveness in response to global challenges. Its development not only creates better conditions for the national business activity, but also a favorable climate to attract foreign investments in other sectors of the national economy, because a good infrastructure development level is a prerequisite for effective and efficient business operations. Under conditions of shortage and high prices on the national market of investment resources, attracting state support is a high priority for Russian enterprises in the telecommunications sector.

In big cities, the telecommunications market is nearly saturated, and significant growth in the number of subscribers is possible only by development of new, most often hardly accessible areas where they live. At the same time, the basic limitation for operators in implementation of projects aimed at attracting new subscribers in hardly accessible regions is the need for large-scale investments in basic telecommunications infrastructure in these regions. However, through introduction of operators' innovations in the internal business processes, the cost maintenance value of a new subscriber will be low. Therefore, when implementing such infrastructure projects, operators rely on state support.

At the same time, one of the key objectives of the state in the area of telecommunications is to ensure that citizens have access to modern telecommunications services irrespective of their place of residence. This is stated in the government program of the Russian Federation «Information Society (years 2011-2020)» [4]. This program envisages establishment of a modern information and telecommunications infrastructure across Russia and reduction of the «digital gap» of some federal territorial unites of the Russian Federation.

The issue of public-private partnership (PPP) in the telecommunications sector is also highly topical in world practice. The World Bank, in particular, pays close attention to PPP projects in the telecommunications sector. The official website of the World Bank [7] constantly updates information on the regulatory environment of the telecommunications sector in various countries (licensing, tariff regulation, universal communication services) and posts examples of implemented PPP projects (cases) in the European Union, Canada, USA, Australia and Singapore.

Total capital investments in the telecommunications sector in Russia in 2013 came to 270.7 billion rubles [4] and the commitment rate of the federal budget to solve government tasks in the telecommunications sector is no more than 15 billion rubles per year [1].

It is obvious that the state's capabilities to finance the telecommunications sector are much lower than the financial possibilities of the private sector. Therefore, the task of finding optimal PPP models between the state and the largest communication operators for development of state-of-the-art communications services in hardly accessible regions is extremely crucial.

The specifics of an investment project implemented under the terms and conditions of PPP are that it is important to calculate the efficiency of its implementation for the company at minimum cost of the state and on the condition that the project is socially minded. Therefore, when considering project implementation under PPP terms both the state and private company face the task of building a project model which will simultaneously take into account the interests of private companies and of society as a whole.

\section{Algorithm for applying simulation modeling of the investment project in the telecommunications sector and its parameters}

The implementation of investment projects in the area of cellular communication takes place under conditions of uncertainty, so even a qualitative business plan of the project cannot guarantee that under conditions of Russia's high-risk economy the investment project implemented can ensure the efficiency and profitability laid down in the plan.

Under conditions of uncertainty, one of the most reasonable approaches to the analysis and evaluation of investment projects is simulation modeling. Application of the modeling simulation in the efficiency analysis of investment projects makes it possible not only to make a reasonable decision about implementation or rejection of one or another investment project, but also identify scenarios leading to the best and the worst results of the project being analyzed. This, in turn, can contribute to the timely adjustment of the project implementation parameters in order to achieve maximum benefit on the investments and justification for applying the publicprivate partnership mechanisms.

For that reason, it becomes urgent to develop an integrated algorithm for applying simulation modeling in an investment analysis when working in the cellular communication market [5].

The following algorithm is proposed for applying simulation modeling to investment analysis in the telecommunications sector. It consists of eight stages (Fig. 1). 


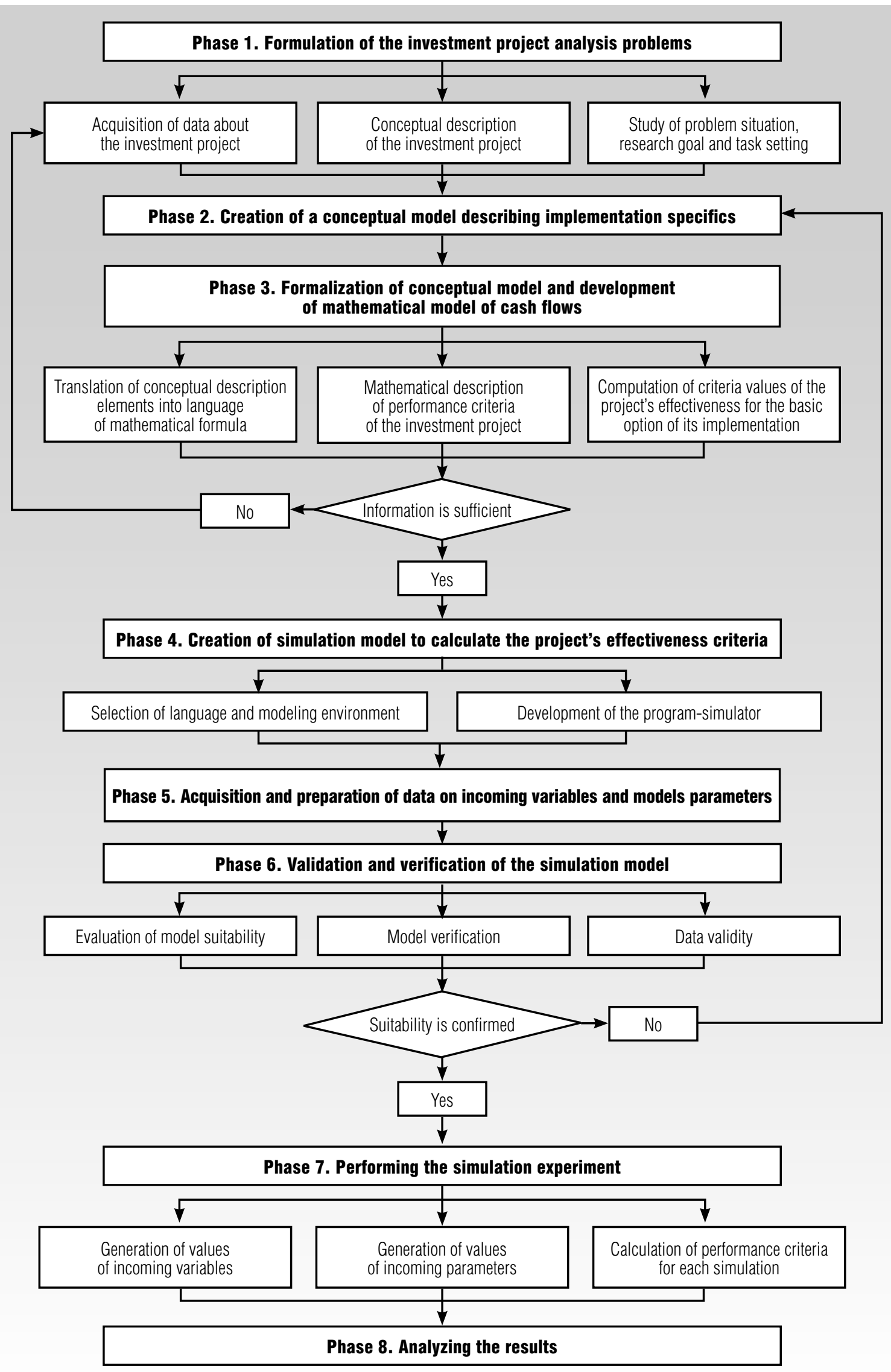

Fig. 1. General algorithm for applying simulation modeling to the investment analysis 
The most important and critical stages of the proposed algorithm are the stages of constructing conceptual, mathematical and simulation models of the performance criteria of the investment project under consideration.

In the phase of conceptual model development the real system transfers to the logical scheme of its operation and the following steps are performed:

$\diamond$ determine the model structure - static and dynamic description of the investment project;

$\diamond$ define the system boundaries, describe the environment, as well as its most essential elements and properties which can affect the final result of the investment project under consideration;

$\diamond$ develop a list of random variables and deterministic parameters, functional dependencies, constraints and criteria of efficiency of the cellular operator's investment project. The variables and parameters should be selected from the following list of values that characterize the activities of the cellular communication operator: number of subscribers, call duration for different types of calls (within the operator's network, to numbers of other operators, to numbers of fixed-line telephony), the number of sms- and mms-messages sent, the amount of data transferred, the scope of other services provided, cost and net cost of one minute of a telephone call for various types of calls, cost and net cost of sending one sms- and mms-message, cost and net cost of transmitting one unit of data, cost and net cost of providing a unit of other services, value of dealership fees and other values at the discretion of the developers.

It is proposed to use the following values in the proposed model as parameters (constant values):

$\downarrow$ amount of investments required to develop the telecommunications infrastructure;

$\checkmark$ cost of one minute of outgoing call;

$\checkmark$ cost of an outgoing message;

$\downarrow$ cost of transmitting a unit of data;

$\uparrow$ discount rate;

$\checkmark$ project implementation period (period of construction and operation).

The project implementation period includes the period of facility construction and operation. Under standard conditions, the time required for completion of the construction cannot be precisely identified, since delays to the delivery of works is a common practice. On the other hand, if we do not specify the period of construction and specify only the project implementation period, the investor will be interested in reducing the construction period in order to maximize the facility operation period during which the investor derives revenue. This will have a negative impact on the quality of construction work. Therefore, the time period for facility construction and operation should be set as parameters of the investment project and indicated in the PPP contract.

The following values are proposed for assignment to the model variables:

$\diamond$ price of one minute of an outgoing call;

$\downarrow$ price of an outgoing message;

$\checkmark$ cost of transmitting a unit of data;

$\diamond$ number of subscribers;

$\downarrow$ number of outgoing calls;

$\checkmark$ average duration of an outgoing call;

$\checkmark$ number of outgoing messages per subscriber;

$\downarrow$ volume of data transmitted (traffic) per subscriber;

$\checkmark$ government take in the investment financing.

For performing simulation experiment, the sample size must ensure its representativeness. This is determined for each random variable. At the end of the simulation experiment, a number of values of performance criteria of the investment project are expected to be received. For analysis of the modeling results, the law of distribution of the resulting indicator of the investment project is determined, and on this basis the project risks can be assessed. For this purpose, the expectation function and mean-square deviation indicators, as well as various probability measures, should be calculated. The result is that, for example, it will be fair to say with a definite probability that the value of the performance criterion of the investment project of the cellular operator will not be below a certain value, or determine the probability of obtaining values of performance criteria indicating the inefficiency of the investment project.

The application of the proposed algorithm will make it possible to quantify the risks of the investment project in the cellular market and make a justified decision about implementation of the investment project using the PPP mechanism, or decide against its implementation.

\section{Criteria of effectiveness of the investment project in the telecommunications sector under the terms of a public-private partnership}

The effectiveness of the investment project is a category reflecting the adherence of the project generating this investment project (IP) to the aims and interests of its participants [1].

It is common practice to refer the effectiveness of the project as a whole and the effectiveness of participating in the project to types of effectiveness of the investment projects (Fig. 2). 


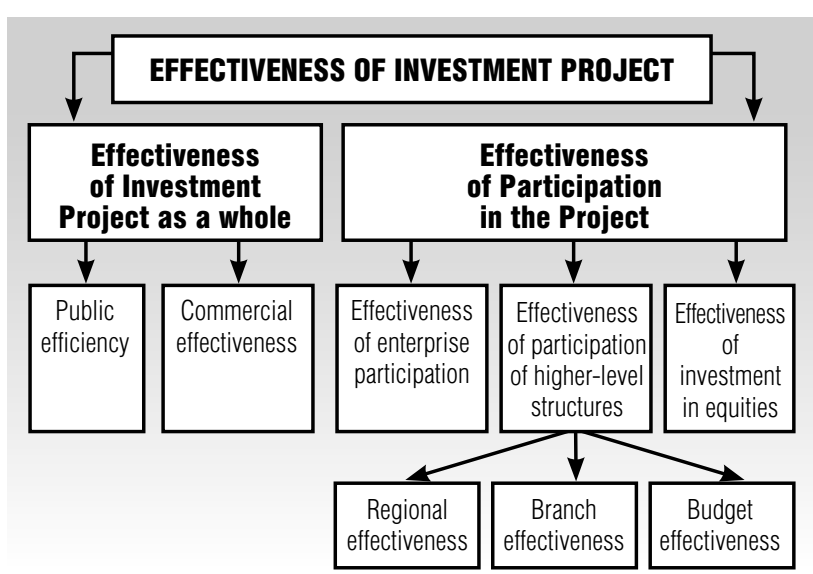

Fig. 2. Effectiveness of the investment project

The effectiveness of the project as a whole is estimated in order to determine the potential attractiveness of the project to potential participants and fundraising. It includes public (social and economic) efficiency and commercial effectiveness of the project.

The indicators of public efficiency account for social and economic consequences of the investment project implementation for society as a whole, including both immediate results and costs of the project, and «external» results, namely the costs and results in related economy sectors, environmental, social and other non-economic effects.

Indicators of the commercial effectiveness of the project account for financial implications of its implementation for the participant implementing the investment project, on the assumption that the participant bears all the necessary project costs and enjoy all its results.

The effectiveness of participation in the project is determined in order to verify the investment project implementation and interest of all project participants in the project.

Prior to assessment of effectiveness, the social significance of the project is determined by evaluation of experts. The social significance (scale) of the project is determined by the effect of the project implementation results on at least one of the internal or external markets: financial, products and services, labor and other markets, as well as on the ecological and social environment.

Further assessment is conducted in two phases.

The first phase calculates the effectiveness indicator of the project as a whole. For socially significant projects, their social efficiency is evaluated first. If the social efficiency is improper, such projects are not recommended for implementation and cannot qualify for state support. If their social efficiency turns out to be sufficient, their commercial effectiveness is assessed next. If the commercial effectiveness of the socially significant IP is insufficient, a recommendation is made to address the pos- sibility of applying various forms of support which could increase the IP commercial effectiveness to an acceptance level. The subject of public-private partnership and selection of its implementation methods then comes out.

The second phase of assessment is performed after development of the funding model. This phase specifies a list of participants and identifies the financial feasibility and participation efficiency in each participant project.

On this basis, the following algorithm for constructing an optimal model of the PPP project is proposed in terms of its effectiveness (Fig. 3).

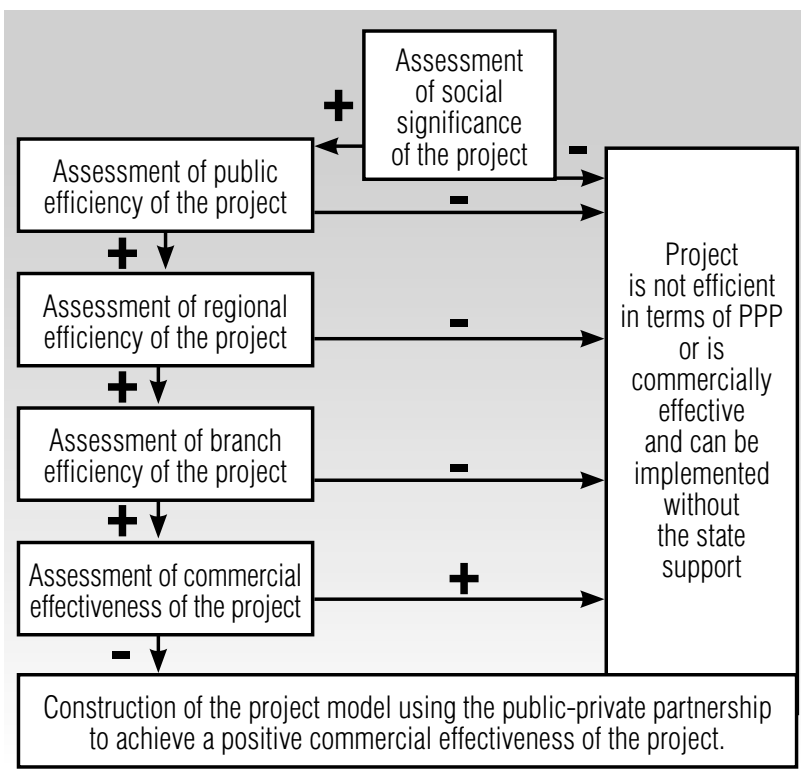

Fig. 3. Algorithm for constructing an optimal model of PPP project in terms of its effectiveness

It is recommended to use the following indexes as the main indicators to calculate IP effectiveness:

$\downarrow$ net present value;

$\checkmark$ internal rate of return;

$\downarrow$ need for additional financing;

$\downarrow$ profitability indexes of expenses and investments;

$\checkmark$ payback period.

The conditions of financial feasibility and performance indexes are calculated on the basis of cash flow, whose specific components depend on the estimated kind of effectiveness.

The most important indicator of project effectiveness is net present value (NPV, another name is integral effect), i.e. the accumulated discounted effect for the accounting period. NPV is calculated by the formula:

$$
N P V=\sum_{m} C F_{m} \frac{1}{(1+E)^{\left(t_{m}-t_{\theta}\right)}}
$$

where $C F_{m}$ is a cash flow at the end of $m$-th step; 
$E$ is the discount rate;

$t_{o}$ is a beginning of a project;

$t_{m}$ is an end of $m$-th step.

In order to recognize that the project if efficient in terms of the investor, the project $N P V$ should be positive. When comparing alternative projects, priority shall be given to the project with a higher $N P V$, provided that $N P V$ is positive.

Another effectiveness indicator is the internal rate of return (IRR, other names are internal rate of discount, internal rate of profit margin). In the most common case of IP beginning with investment outlay and having a positive net profit, the internal rate of return is a positive number $E_{0}$ which satisfies the following requirements:

$\diamond$ with a discount rate $E=E_{0}$ becomes zero in the net present value of the project;

$\diamond$ this is a singular number.

Payback period with regard to discounting is the period of time from the initial moment to payback moment with regard to discounting. The payback moment with regard to discounting is referred to as the earliest time in the accounting period after which the current net present value $N P V(k)$ becomes greater than zero and keeps on negative. When assessing the effectiveness, the payback time usually acts as a limitation.

The need for additional financing with regard to discount (AF, other names are project costs, capital risk) is a maximum absolute value of the negative accumulated discounted balance of the investment and operational activities. The AF value indicates the minimum discounted amount of the external financing of the project required for its financial feasibility.

Profitability indexes characterize a (relative) project benefit per investment. They can be calculated both for discounted and non-discounted cash flows.

Net present value is proposed as an effectiveness criterion of investment projects in the telecommunications sector under public-private partnership conditions. It is proposed to find its maximum value with a given amount of investment and minimum state participation.

\section{Investment project model for the telecommunications sector under conditions of public-private partnership: parameters and their association}

The basic logic of the mathematic model construction procedure is to determine the parameters and variables that are included in the model, as well as the type of distribution, which these variables are subject to, and interdependences (functional and probabilistic relationships between variables).
Compliance with such a procedure is necessary to create a model that would be as follows:

$$
N P V=f\left(x_{1}, \ldots, x_{i}, \ldots, x_{n} ; a_{1}, \ldots, a_{j}, \ldots, a_{m}\right),
$$

where $x_{i}$ are variables (cash flow components being random values); $n$ is a number variables;

$a_{j}$ are fixed model parameters, i.e. those cash flow components which in the previous analysis were identified as independent or little dependent on the external environment, and therefore are considered as deterministic values;

$m$ is a number of model parameters.

To construct a mathematical model of the investment project in the telecommunications sector under the terms of PPP, it is proposed to select the following model parameters and variables:

- model parameters:

$\downarrow$ the amount of investments required for creation of telecom infrastructure $(I)$;

$\checkmark$ the cost of one minute of outgoing call of $i$-type in the $t$-th period $\left(C X_{i t}\right)$;

$\downarrow$ the cost of an outgoing message of $i$-type in the $t$-th period $\left(C Y_{i t}\right)$;

$\downarrow$ the cost of transmission of a unit of data in the $t$-th period $\left(C Z_{t}\right)$;

$\checkmark$ fixed costs in the $t$-th period $\left(F C_{t}\right)$;

$\downarrow$ discount rate $(r)$;

$\checkmark$ duration of the project $(T)$;

$\checkmark$ period of project construction $\left(T_{i}\right)$;

$\downarrow$ useful lifetime of the project $\left(T_{0}\right)$;

-model variables:

$\diamond$ price of a minute of outgoing call of $i$-type in the $t$-th period $\left(P X_{i t}\right)$;

$\diamond$ price of an outgoing message of $i$-type in the $t$-th period $\left(P Y_{i t}\right)$;

$\diamond$ the cost of transmitting a data unit in the $t$-th pe$\operatorname{riod}\left(P Z_{t}\right)$;

$\diamond$ number of outgoing calls of $i$-type per subscriber in the $t$-th period $\left(X_{i t}\right)$;

$\diamond$ average duration of the $i$-type of outgoing calls for $t$-th period $\left(D_{i t}\right)$;

$\diamond$ a number of outgoing messages of $i$-type per subscriber in the $t$-th period $\left(Y_{i t}\right)$;

$\diamond$ amount of data transferred (traffic) per subscriber in the $t$-th period $\left(Z_{t}\right)$;

$\diamond$ state participation in investment financing $(j)$.

Therefore, the target function of the project can be written as follows:

$$
N P V=\sum_{t=1}^{T_{0}-T_{i}} \frac{N_{t} S-F C_{t}}{(1+r)^{T_{0}-T_{i}}}-I(1-j),
$$

where $S=P_{i t}\left(P X_{i t}-C X_{i t}\right)+Y_{i t}\left(P Y_{i t}-C Y_{i t}\right)+Z_{t}\left(P Z_{t}-C Z_{t}\right)$. 
The next investigation stage is calculation of the project function with specified project parameters and various options of possible values of variables with a restricted service prices set by a private company under the state anti-monopoly regulation and restricted capabilities of the public participation in the project.

\section{Conclusion}

The developed performance evaluation algorithm and criteria for the investment project on the terms of PPP made it possible to construct a model connecting the basic project parameters (duration, amount of investment, rate, demand) with the expected performance indexes.

The model identified seven parameters and nine variables.

The model makes it possible to calculate various sce- narios to determine maximum effectiveness with restricted volume of state investments.

The results of calculation made on the basis of the proposed model can be used by the authorities or public financial institutions to reach a decision about participation in a project. It is proposed to document the model application and evaluation criteria in the rules of granting subsidies for the implementation of PPP projects.

The proposed algorithm for analysis of the investment projects under PPP terms has large-scale capabilities and makes it possible to adapt them to the available analysis models of investment projects, as well as modify them with due regard to actual conditions of implementation of the investment project.

The disadvantages of this approach are the subjectivity in selection of restrictions on the variables, including the volume of state investments.

\title{
References
}

1. The Federal Law of 03.12.2012 No. 216-FZ (2012) O federal'nom bjudzhete na 2013 god i na planovyj period $2014 \mathrm{i}$ 2015 godov [On the Federal Budget for 2013 and the planning period of 2014 and 2015 years]. Rossiyskaya Gazeta, no. 5956 (December 7, 2012), p. 19 (in Russian).

2. The Government of Russian Federation (2014) Gosudarstvennaja programma Rossijskoj Federacii «Informacionnoe obshhestvo (2011-2020 gody)» [State program of the Russian Federation «Information society (2011-2020)»]. Collection of Russian Legislation, no. 18 (May 5, 2014), p. 2159 (in Russian).

3. Kossov V.V., Livshits V.N., Shakhnazarov A.G. (2000) Metodicheskie rekomendacii po ocenke jeffektivnosti investicionnyh proektov [Guidelines for assessing the effectiveness of investment projects]. Moscow: Economics (in Russian).

4. The Ministry of Communications and Mass Communications of the Russian Federation (2013) Investicii v otrasl'svjazi $i$ vvod v dejstvie moshhnostej [Investments in the communications industry and commissioning of facilities]. Available at: http://minsvyaz.ru/ru/pages/statistika-otrasli/\#section-81 (accessed 25 March 2015) (in Russian).

5. Oblakova A. (2009) Imitacionnoe modelirovanie investicionnoj dejatel'nosti v sfere uslug sotovoj svjazi [Simulation of investment activity in the field of mobile communication services]. PhD Thesis. Moscow, Finance Academy under the Government of the Russian Federation (in Russian).

6. Oblakova A. (2009) Imitacionnoe modelirovanie investicionnoj dejatel'nosti na rynke uslug sotovoj svjazi [Simulation of investment activity on the market of mobile communication services]. Proceedings of the 4th All-Russian Conference «Simulation. Theory and practice», 21-23 October, 2009, Saint Petersburg, pp. 194-198 (in Russian).

7. The World Bank (2015) Telecommunications / information \& communication technology PPPs. Available at: http://ppp. worldbank.org/public-private-partnership/sector/telecom (accessed 01 April 2015).

\section{МОДЕЛЬ ОПТИМАЛЬНОГО ПРОЕКТА ГОСУДАРСТВЕННО-ЧАСТНОГО ПАРТНЕРСТВА В СЕКТОРЕ ТЕЛЕКОММУНИКАЦИЙ}

\author{
С.В. МАЛЬЦЕВА \\ доктор технических наук, профессор кафедры инноваций и бизнеса в сфере \\ информационных технологий, Национальный исследовательский университет \\ «Высшая школа экономики»
}

Адрес: 101000, г. Москва, ул. Мясницкая, д. 20

E-mail: smaltseva@hse.ru 


\section{П.В. КОТЕЛЬНИКОВА}

аспирант кафедры инноваций и бизнеса в сфере информационных технологий, Национальный исследовательский университет «Высшая школа экономики»; главный инспектор Счетной палаты Российской Федеращии

Адрес: 101000, г. Москва, ул. Мясницкая, д. 20

E-mail: kotelnikovapolina@gmail.com

В статье представлена модель инвестиционного проекта в секторе телекоммуникаций на условиях государственно-частного партнерства (ГЧП), позволяющая связать основные параметры проекта (срок, объем инвестиций, тариф, спрос) с ожидаемыми показателями эффективности. При рассмотрении параметров и показателей эффективности проекта учитываются интересы как государства, так и частной компании.

Алгоритм построения модели и критерии оценки эффективности разработаны на основе стандартов, утвержденных для оценки инвестиционных проектов с долей государственного участия, а именно Методическими рекомендациями по оценке эффективности инвестиционных проектов, утвержденных Минэкономики РФ, Минфином РФ, Госстроем РФ от 21 июня 1999 г. № ВК 477.

В работе допускается, что для частной компании самым важным критерием оценки эффективности проекта является максимум показателя чистой приведенной стоимости (чистого приведенного дохода) проекта, который характеризуется превышением суммарных денежных поступлений над суммарными затратами для данного проекта с учетом неравноценности эффектов (затрат и результатов), относящихся к различным моментам времени. Таким образом, чем выше данный показатель, тем больший интерес у частной компании вызывает участие в данном проекте.

Представляется, что с точки зрения государства наиболее важными являются два фактора: наличие общественной значимости проекта и минимум затрат государства на реализацию инвестиционного проекта в условиях ограниченной возможности расходования бюджетных средств. Общественная значимость проекта определяется экспертным путем как влияние результатов реализации проекта хотя бы на один из внутренних или внешних рынков: финансовых, рынков продуктов и услуг, рынка труда и т.д., а также на экологическую и социальную обстановку.

Модель позволяет рассчитать различные сценарии для определения оптимальных параметров проекта, обеспечивающих максимальную эффективность при заданном ограничении на объем бюджетных инвестиций.

Результаты расчетов по предлагаемой модели могут быть использованы для принятия органами власти или государственными финансовыми институтами развития решений об участии в проекте. Использование модели и критерии ее оценки предлагается зафиксировать в правилах предоставления субсидии на реализацию таких проектов.

Ключевые слова: государственно-частное партнерство, инвестиционный проект, эффективность проекта, имитационное моделирование, телекоммуникации.

Цитирование: Maltseva S.V., Kotelnikova P.V. Model of an optimal public-private partnership project in the telecommunications sector // Business Informatics. 2015. No. 4 (34). P. 24-31. DOI: 10.17323/1998-0663.2015.4.24.31.

\section{Литература}

1. Федеральный закон от 03.12.2012 № 216-Ф3 «О федеральном бюджете на 2013 год и на плановый период 2014 и 2015 годов» // Российская газета. 2012. № 5956, 07.12.2012. С. 19.

2. Государственная программа Российской Федерации «Информационное общество (2011-2020 годы)» // Собрание законодательства Российской Федерации. 2014. №18, 05.05.2014. С. 2159.

3. Коссов В.В., Лившиц В.Н., Шахназаров А.Г. Методические рекомендации по оценке эффективности инвестиционных проектов. М.: Экономика, 2000. $421 \mathrm{c.}$

4. Инвестиции в отрасль связи и ввод в действие мощностей (2013 г.) [Электронный pecypc]: http://minsvyaz.ru/ru/pages/statistikaotrasli/\#section-81 (дата обрашения 25.03.2015).

5. Облакова А.В. Имитационное моделирование инвестиционной деятельности в сфере услуг сотовой связи. Дис. ... канд. экон. наук. М., 2009. 203 с.

6. Облакова А.В. Имитационное моделирование инвестиционной деятельности на рынке услуг сотовой связи // Материалы IV всероссийской научно-практической конференции «Имитационное моделирование. Теория и практика», 21-23 октября 2009 г., г. Санкт-Петербург. СПб, 2009. С. 194-198.

7. Telecommunications / Information \& Communication Technology PPPs [Электронный pecypc]: http://ppp.worldbank.org/publicprivate-partnership/sector/telecom (дата обращения 01.04.2015). 